\title{
Complejo Enterobacter cloacae
}

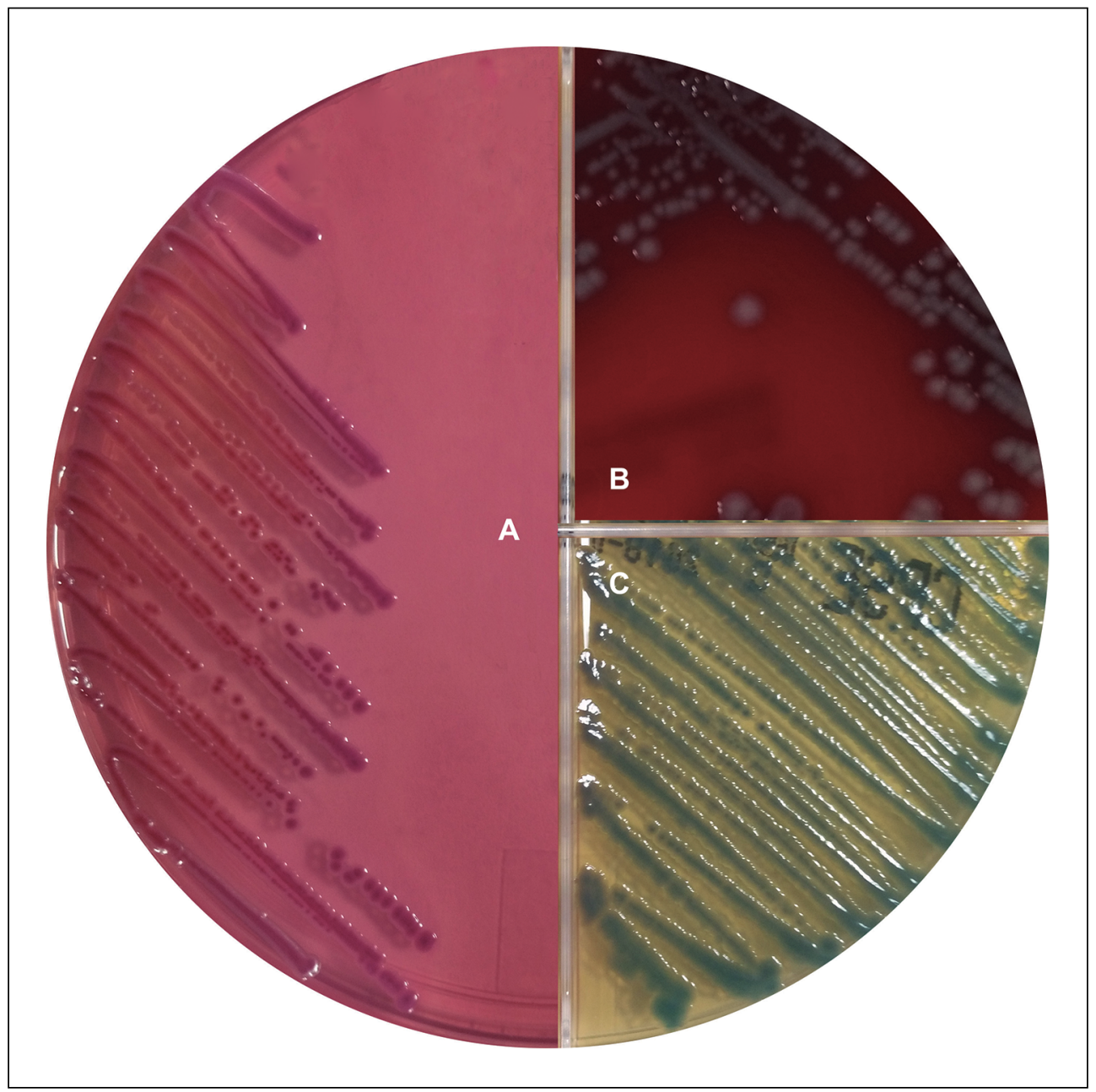

Figura 1. Enterobacter hormaechei con 24 h de incubación. A) agar MacConkey; B) agar sangre de cordero 5\%; C) agar CPS (bioMerieux $\left.{ }^{\circledR}\right)$. 


\section{Complejo Enterobacter cloacae}

Las bacterias del genero Enterobacter son bacilos gramnegativos pertenecientes a la familia Enterobacteriaceae, ampliamente distribuidos en la naturaleza. Se les puede encontrar en el suelo, agua y como parte de la microbiota de animales, insectos y tracto gastrointestinal humano. Incluye 21 especies dentro de las cuales se define el complejo Enterobacter cloacae. Fue descrito en 1890 como Bacillus cloacae, sufriendo varios cambios taxonómicos hasta ser nombrado como E. cloacae por Hormaeche y Edwards en 1960. La relación dentro de este complejo se establece a partir de la hibridación ADN-ADN de genomas completos, pruebas bioquímicas y por la secuenciación del 16S ARNr y del gen hsp60.

El complejo E. cloacae incluye 12 clústeres dentro de los que se definen seis especies: Enterobacter asburiae, Enterobacter cloacae (con tres clústeres y dos subespecies), Enterobacter hormaechei (con tres subespecies), Enterobacter kobei, Enterobacter ludwigii y Enterobacter nimipressuralis. Este último no está relacionado con infecciones en seres humanos y recientemente fue reclasificado dentro del género Lelliottia. La mayoría de las infecciones en humanos son causadas por E. hormaechei y E. cloacae Cluster III, siendo agentes comunes de IAAS, principalmente bacteriemias, neumonías asociada a ventilación mecánica, infecciones urinarias e intra-abdominales complicadas.

En los laboratorios clínicos el cultivo se realiza en medios habituales como agar sangre o agar MacConkey y la identificación del complejo se puede hacer por pruebas bioquímicas convencionales. Son cepas no pigmentadas, la mayoría de las veces móviles, catalasa positiva, oxidasa y ADNasa negativas, fermentan la glucosa, reducen los nitritos, reacción de indol negativa, decarboxilan la ornitina, no decarboxilan la lisina y son citrato y ureasa positiva. Sin embargo, la identificación de especies dentro del complejo es difícil y requiere pruebas adicionales, como la hidrólisis de esculina, fermentación de la sacarosa, dulcitol y D-sorbitol, y producción de putrescina, entre otras. Los métodos automatizados son capaces de distinguir E. cloacae y E. asburiae, pero no las otras especies.

La introducción de sistemas de espectrometría de masa (MALDI-TOF MS) ha permitido identificar las cepas de $E$. nimipressuralis; sin embargo, puede presentar baja discriminación entre las otras especies, por lo que muchas veces se requiere el uso de técnicas de RPC o de secuenciación para la identificación definitiva.

El estudio de susceptibilidad se realiza según los mismos estándares de todas las enterobacterias. La mayoría de los reportes de susceptibilidad dentro del complejo incluyen cepas de E. cloacae, E. asburiae y E. hormaechei.

Entre los antibacterianos no $\beta$-lactámicos, pueden ser susceptibles a fluoroquinolonas, cotrimoxazol, cloranfenicol y aminoglucósidos; sin embargo, se ha descrito resistencia a todos ellos. La resistencia a colistín y tigeciclina es inhabitual.

Entre los $\beta$-lactámicos, el complejo E. cloacae se considera intrínsecamente resistente a las aminopenicilinas, cefalosporinas de primera generación y cefoxitina debido a la presencia de $\beta$-lactamasas del tipo AmpC con distintos grados de expresión, lo que implica susceptibilidad variable a cefalosporinas de tercera y cuarta generación. Además, se han descrito cepas productoras de $\beta$-lactamasas de espectro extendido. Si bien la presencia de carbapenemasas es poco frecuente, en la última década se han descrito carbapenemasas de clase A (en especial KPC), clase B y clase D (en especial oxa-48) con frecuencias variables entre países, lo que ha contribuido al aumento de la resistencia a carbapenémicos y dificultado su manejo.

\section{Referencias bibliográficas}

1.- Mezzatesta ML, Gona F, Stefani S. Enterobacter cloacae complex: clinical impact and emerging antibiotic resistance. Future Microbiol 2012; 7: 887-902.

2.- Pavlovic M, Konrad R, Iwobi AN, Sing A, Busch U, Huber I. A dual approach employing MALDI-TOF MS and real-time PCR for fast species identification within the Enterobacter cloacae complex. FEMS Microbiol Lett 2012; 328: 46-53.

Francisco Silva y TM. Pabla Martínez O. Servicio de Laboratorio Clinico, Hospital Clínico Universidad de Chile.

Correspondencia a: fsilva@hcuch.cl 